\title{
LOOKING FOR A LONG-TERM RECORD IN THE GREATER YELLOWSTONE ECOSYSTEM: THE 2010 FIELD SEASON AT THE STINKING SPRINGS ROCKSHELTER, TETON COUNTY, WYOMING
}

\author{
KENNETH P. CANNON $\uparrow$ MOLLY BOEKA CANNON \\ USU ARCHEOLOGICAL SERVICES AND UTAH STATE UNIVERSITY $\uparrow$ LOGAN
}

\begin{abstract}
$\uparrow$ ABSTRACT
The mountainous environment of northwestern Wyoming is not known for the preservation of organic remains, specifically that of vertebrate species. The paucity of vertebrate remains has hampered the ability of researchers to understand the evolution of the Quaternary mammalian community, which is in sharp contrast to the detailed understanding of the region's geologic, climatic, and vegetation history. The few sites that have produced vertebrate remains have been largely confined to dry caves and rockshelters in the surrounding region and a few open air archaeological sites. In southern Teton County we have located a large rockshelter at the mouth of Hoback Canyon that presents a unique opportunity to recover a long-term mammalian record documenting Quaternary paleoecological change. Hand augering in 2006 revealed evidence of intact, datable strata likely to yield a robust mammalian faunal record. A radiocarbon age of $4210 \pm 50$ yrs BP was obtained from Ponderosa pine charcoal at a depth of $90 \mathrm{~cm}$ below surface, suggesting a record extending at least to the midHolocene.
\end{abstract}

In 2010, the Utah State University Field School conducted limited controlled excavations in two $1 \mathrm{~m}^{2}$ units. Excavations produced additional evidence of stratified deposits to a depth of $1.9 \mathrm{~m}$. Remains recovered include lithic debitage, hearth features, faunal remains, and a possible large mammal processing area. Two specimens, one on Pinus charcoal from a depth of $1.9 \mathrm{~m}$ and a portion of a bighorn sheep mandible from $1.0 \mathrm{~m}$, were submitted for radiocarbon assay. The ages are $4350 \pm$ $25 \mathrm{yrs} \mathrm{BP}$ and $3360 \pm 25 \mathrm{yrs} \mathrm{BP}$, respectively.

The size, geology, and setting above the Hoback River in a natural bottleneck between ungulate winter and summer ranges make the Stinking Springs rockshelter an excellent candidate for archaeological and paleoecological investigation. Proposed future investigations are designed to assess the rockshelter for the presence of preserved vertebrate remains and the deposit's potential to address a number of key issues of how the mammalian community developed during the Quaternary in relation to large-scale (e.g., glaciation) and small-scale climatic (e.g., post-glacial maximum warmth, Little Ice Age) shifts. The anticipated record will not only provide information on the mammalian community structure, but will also provide a paleoecological model for understanding the economies of precontact Native American groups who lived in the region, and will also provide key information that can be applied to future management of threatened species and their habitat (e.g., pronghorn antelope).

\section{INTRODUCTION}

The recovery of vertebrate remains from Quaternary deposits is of particular interest to scientists studying issues of post-glacial biotic community structure (CUMYNP 2002), precontact Native American economies in the Greater 
Yellowstone Area (Cannon et al. 2001), and the management of large mammals (Cannon and Cannon 2004; Berger et al. 2006; Cannon 2008). However, despite intense work on the precontact archeological record in northwest Wyoming (e.g., Wright 1984; Connor 1998; Cannon et al. 2001), the recovery of organic remains (e.g., botanical and faunal remains) has been elusive (cf., Cannon 1997; Santucci 1998). Our limited understanding of Holocene mammalian biogeography is notable considering the research efforts into climate (Whitlock and Bartlein 1993), vegetation (Whitlock 1993; Whitlock et al. 2008), and glacial history (Good and Pierce 1996).

Preservation and site location are probably key factors. Soils in northwestern Wyoming tend to be shallow, acidic, and subject to bioturbation thereby accelerating chemical and mechanical destruction of organic remains (Cannon et al. 1997). Unique geologic settings, such as caves and rockshelters, provide research opportunities for extracting organic remains that provide direct evidence of paleoenvironmental conditions and subsistence patterns that are not typically preserved in open mountain sites (Finley 2007).

With few open site exceptions (e.g., Goetz site [Cannon and Cannon 2003]), other site types that have proved important in producing organic remains are dry cave and rockshelter sites. These types of sites provide unique research opportunities for understanding long-term patterns of environmental change that are usually not available from open sites, typically at scales with detailed resolution that can be used to examine sophisticated questions of ecosystem dynamics (e.g., Barnosky and Hadly 1994; Hadly 1995; Hadly et al. 1998). Therefore, the Stinking Springs Rockshelter (SSR) has become a potentially important site for revealing a stratified Quaternary record.

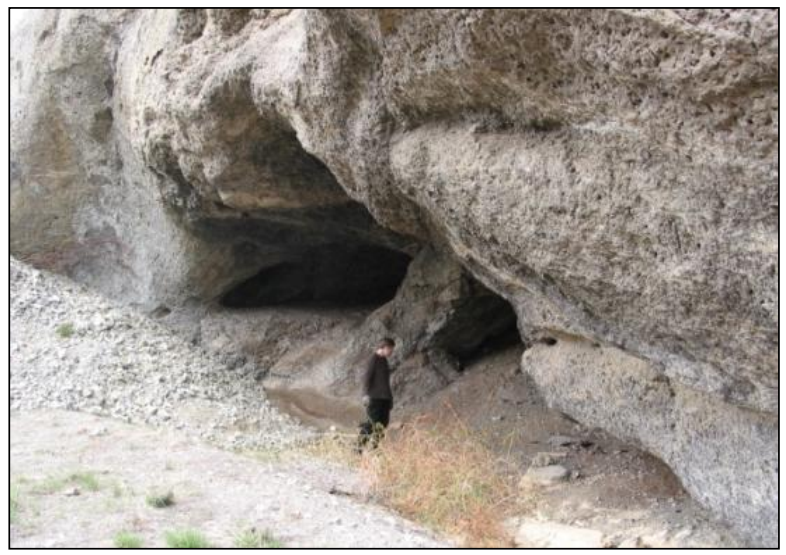

Figure 1. Overview of Stinking Springs Rockshelter (photos by KP Cannon, 16 April 2004).
Hand augering in 2006 revealed evidence of buried deposits to a depth of at least $1 \mathrm{~m} \mathrm{(4210 \pm 50}$ yrs BP) with preservation of organic materials, including mammal bone. Other evidence to support its potential is its relative large size, protective overhang and shelter, and its location adjacent to the Hoback River. The floor of the rockshelter has been buried under road deposits by the original, but long abandoned, road that traversed the Hoback Canyon (Figures 1-2). This historic circumstance has probably protected the record from destruction by unauthorized excavation.

Figure 2. Hand auguring within interior of rockshelter in 2006 (photo by MB Cannon, June 2006).

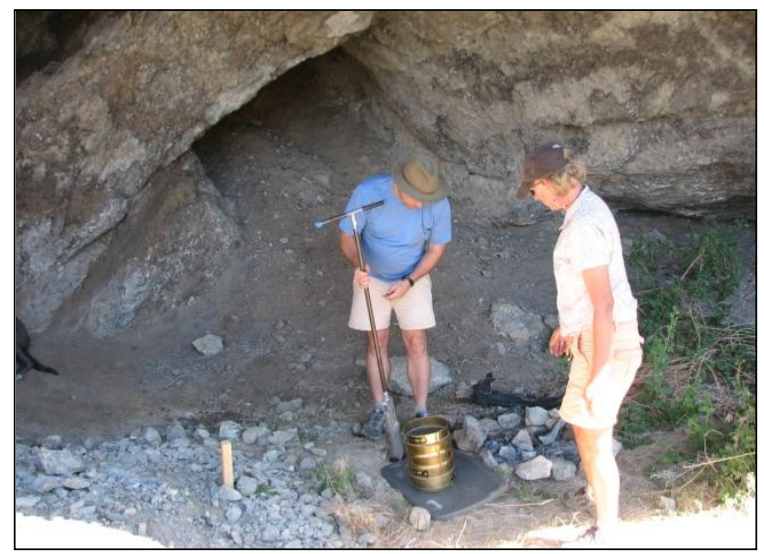

The SSR is located in southern Teton County, Wyoming (T38N R115W, Sect. 3, NW 1/4) along the Hoback River downstream from Hoback Junction at an elevation of $1920 \mathrm{~m}(6300 \mathrm{ft})$ AMSL (Figure 3 ). The rockshelter was probably constructed by erosion of the Mississippian age Madison group limestone (Schroeder 1974). Downslope from the rockshelter is a series of "highly sulfurous springs" which emerge from the Hoback fault where it crosses the Hoback River (Love 1989). The rockshelter is uniquely situated at a natural bottleneck at the entrance to Hoback Canyon (Figure 4). This topographic situation is significant to the migration of large game, such as elk (Cervus elaphus) and pronghorn antelope (Antilocapra americana), between their winter and summer ranges. Other species, such as bison (Bison sp.), may also have used this migration route. The archeological record of the Trappers Point site to the south indicates that these natural bottlenecks have been used by pronghorn for millennia and provide researchers with the opportunity to study long term land use by ungulates in relation to climate change (Miller et al. 1999; Sanders and Miller 2004). Adjacent modern large game migration routes provide additional 


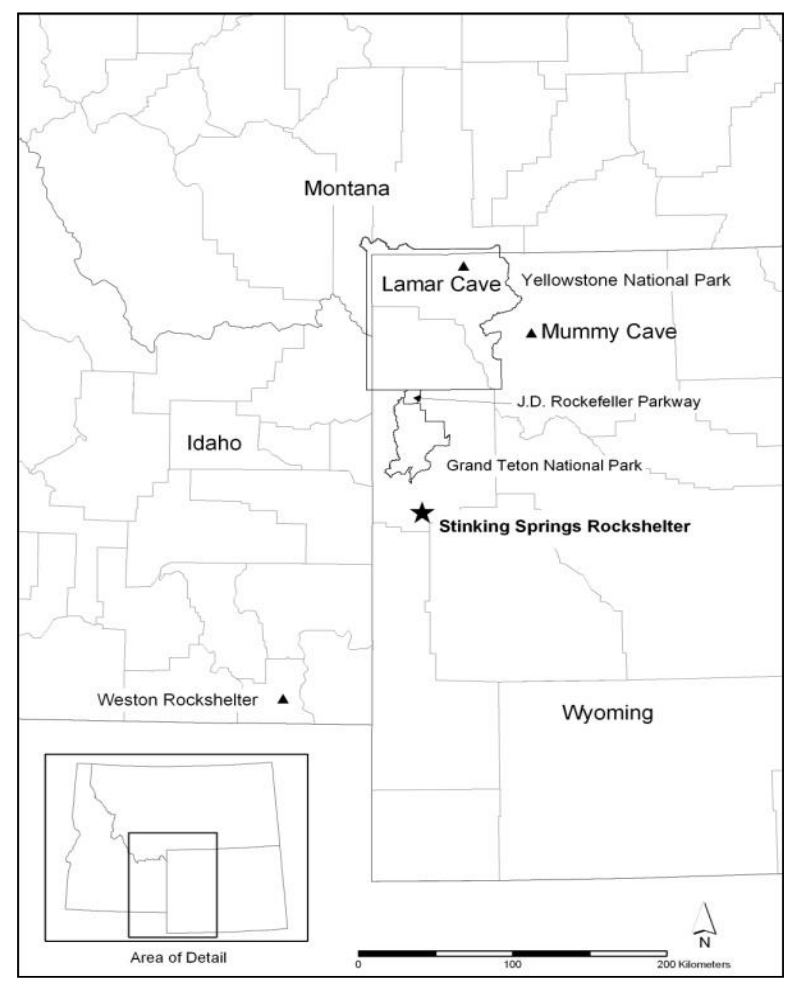

Figure 3. Location of Stinking Springs Rockshelter and other sites mentioned in text.

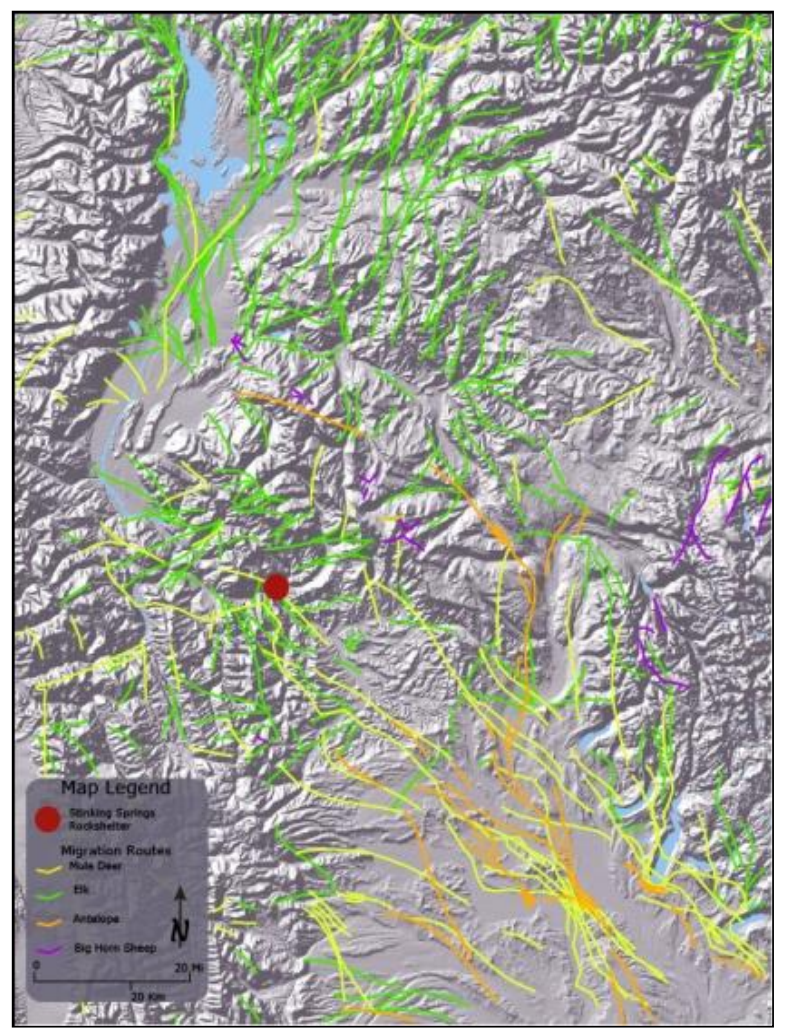

Figure 4. Google Earth image of topographic setting of Stinking Springs Rockshelter. Arrow indicates location of rockshelter. support (Figure 5). Understanding and preserving large mammal migration corridors is recognized as an important conservation issue locally (Feeney et al. 2004) and internationally (Berger et al. 2006).

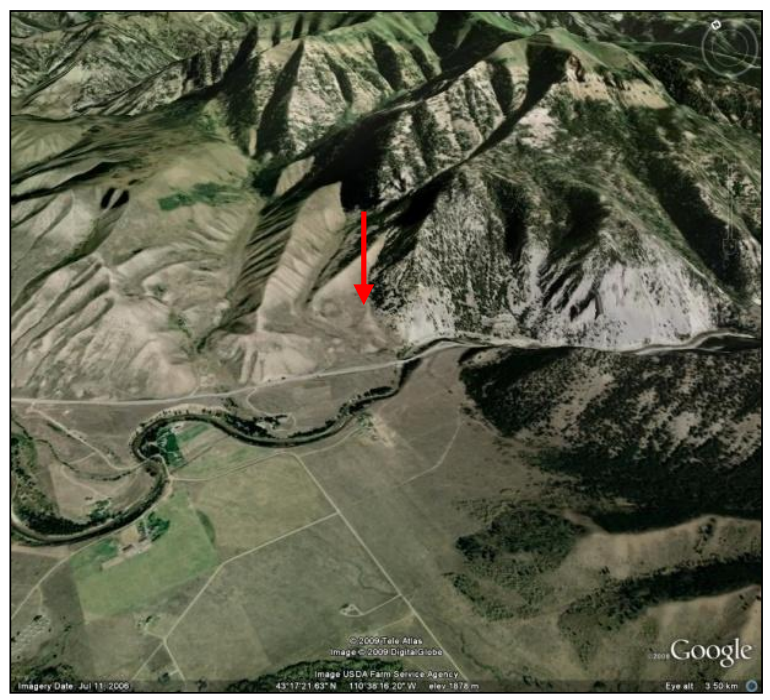

Figure 5. Modern large game migration routes in relation to Stinking Springs Rockehelter.

\section{$\uparrow$ SIGNIFICANCE}

Three cave/rockshelter sites have been excavated in the region (Figure 3), and each has provided an extraordinary record of biotic materials that have allowed sophisticated questions of changes in biogeography and human subsistence over large portions of the Holocene. For example, Mummy Cave located to the east of Yellowstone National Park has produced a record that is nearly $9-\mathrm{m}$ in depth and dates back 10,000 years (Husted and Edgar 2001). Mummy Cave represents the comparative record for the region's cultural history. Despite having been excavated in the mid-1960s the quality of the excavations has allowed continued research of the deposits (Hughes 1988; Kelly 2010). Analysis of the faunal record by Hughes (2004) illustrates changes in bighorn sheep (Ovis canadensis) ecology over the last 10,000 years with respect to climate and the introduction of domestic sheep (Ovis aries).

Excavations at Lamar Cave in the Lamar River valley of Yellowstone National Park has produced a 2000-year-record of small mammal remains (Hadly 1990, 1995). This well-stratified deposit has allowed Hadly to address such topics as variation in small mammal populations in relation to climate change (Hadly 1996), the evolution of the ecology of the Lamar Valley, spatial and temporal 
diversity of mammals (Barnosky and Hadly 1994; Hadly 1999), even the genetic record of pocket gophers (Thomomys sp.) has been extracted from these deposits (Hadly et al. 1998).

To the southwest, the Weston Rockshelter has produced a record of human occupation that dates back 8000 years (Miller 1972). The evidence from this rockshelter provides a picture of selective bighorn sheep hunting (Wright and Miller 1976). The data also provide information on precontact sheep demography that can provide us with insight into how we may manage bighorn sheep for the perpetuation and reintroduction of the species.

While the efforts of the researchers should not be diminished, the sites are widely dispersed and represent over 40 years of dramatic changes in excavation methodologies, techniques, and research interests. For example, the Weston Rockshelter in southeastern Idaho was excavated between 1968 and 1970 (Miller 1972). It is unclear from the report how sediments were processed (probably hand-shaker screens using 1/4-inch mesh), but it is obvious that the sediments were not water-screened thereby limiting recovery of micro-mammals and other paleoecological data. In contrast, the Lamar Cave site was excavated in natural stratigraphic units with all sediments dry-screened through 3-mm mesh during the first field season. In the second field season recovery was maximized through wet screening all sediments through 1-mm mesh (Hadly 1990). With such variable techniques it makes comparison of the data sets difficult, especially in trying to understand the effects of climate change on biotic communities.

Northwestern Wyoming is not known for the preservation of organic materials, or for the presence of caves and rockshelters. For example, only onethird of the caves described by Hill et al. (1976) are present in the Teton County vicinity with many of these being vertical. This is in sharp contrast to areas such as the Bighorn Mountains to the east where over 150 rockshelters have been documented (Finley 2001) and the Snake River Plain to the west (Plew 2000).

In exploring the archaeological record for the Wyoming portion of the GYE over 10,000 precontact sites have been recorded (Figure 6), however, less than one percent are rockshelters/caves, and only two of which have been tested producing faunal remains (Figure 7).

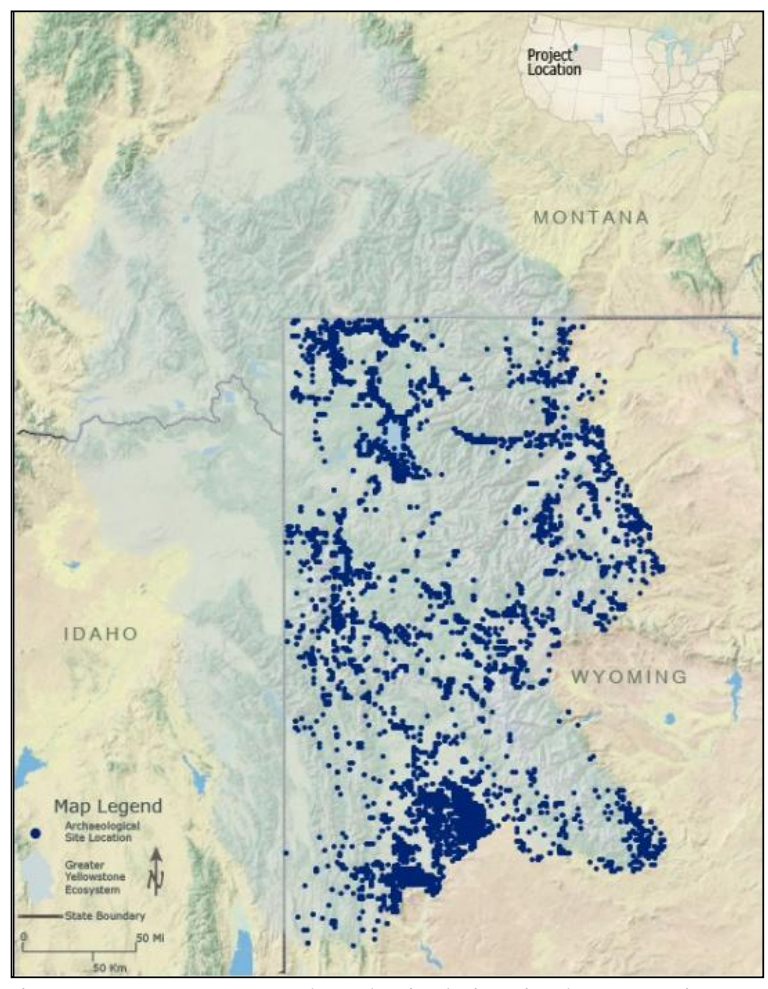

Figure 6. Precontact archaeological sites in the Wyoming portion of the GYE (data provided by the Wyoming State Historic Preservation Office).

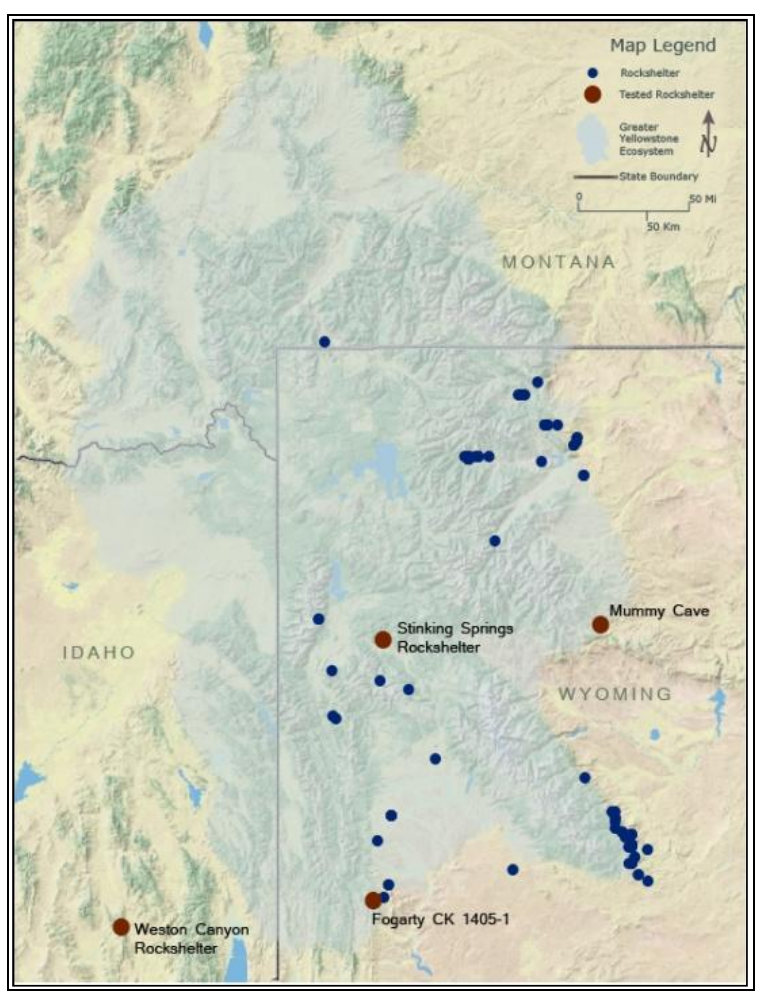

Figure 7. Map of rockshelter/cave sites in the Wyoming portion of the GYE. 
As such, horizontal rockshelters such as the SSR are noteworthy for their research potential. It is thus highly likely that the SSR will yield significant deposits:

- The rockshelter is fairly large in size. Limited excavations (e.g., hand augering) in 2006 produced evidence of preserved bone, plant remains, and other organic materials. A radiocarbon age of 4210 $\pm 50 \mathrm{yrs}$ BP was obtained from charcoal at a depth of $90 \mathrm{cmbs}$.

- Caves and rockshelters in the region are rare, but the few that have been excavated provide a wealth of information in the form of stratified, organic remains that are typically not present in open sites (Figure 8).

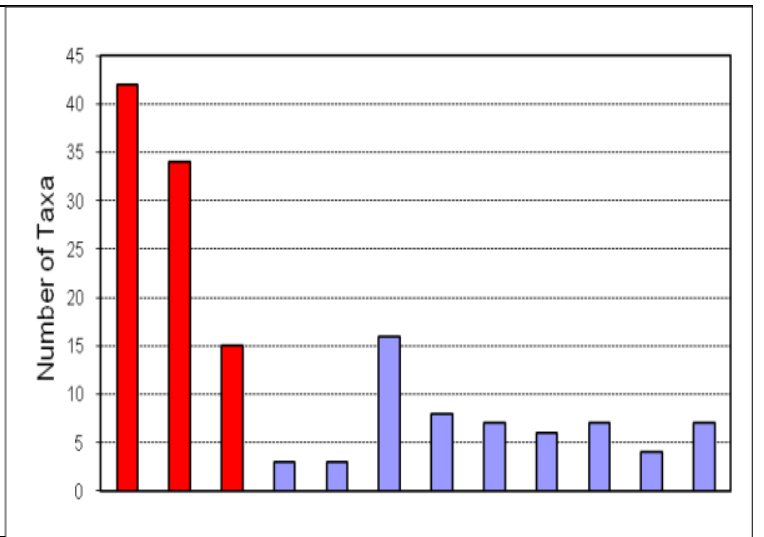

Figure 8. The types of sites that have produced large faunal assemblages, with large numbers of taxa are either rockshelter/caves (red), or open sites (blue) in unique geologic setting that promotes preservation.

- The location of the shelter along a natural bottleneck at the entrance to Hoback Canyon is, and probably has been for millennia, a migration route for ungulates between summer and winter ranges (e.g., Sanders and Miller 2004; Berger et al. 2006).

- The rockshelter is within a kilometer of several life-zones or biotic communities that may have been sampled by human hunters or other predators (e.g., carnivores, raptors) increasing its relevance to addressing questions concerning the evolution of community structure in the post-glacial GYA.

- The site potentially provides an important contrast to Lamar Cave in northern Yellowstone National Park which was under different climatic regimes at different times in the Holocene according to Whitlock and Bartlein (1993). This site provides an important test of their pollen-based model.

- $\quad$ As the FAUNMAP Working Group (1996) has demonstrated, animal communities are of relatively recent age due to individual tolerances of the species. The vertebrate record of the GYA is poorly known (Cannon et al. 2000). This is notable considering all that is known concerning glacial history (Good and Pierce 1996), climate, and vegetation (Whiltock 1993).

\section{Utah State University 2010 Field School}

In June of 2010, students participating in the Utah State University Field School spent six days investigating the SSR. Two $1-\mathrm{m}^{2}$ test units were excavated (Figure 9). The goal of the 2010 work was to quickly excavate these units in order to assess the minimal depth of the deposits. Units were selected based on hand probes ohe sediment that revealed buried deposits and limited rockfall.

Mapping was performed using a Sokkia SRX5 Robotic Total Station. This included topographic features, excavation units, and recovered artifacts. Units were excavated in $10-\mathrm{cm}$ arbitrary levels with sediments being processed using 1/8-inch hand shaker screens.

Test Unit 1 was placed in the central portion of the shelter below the dripline. Test Unit 1 reached a depth of one meter (Figure 10) and produced evidence of cultural deposits, including a fired rock feature (Figure 11) and a bighorn sheep mandible (Figure 12). A portion of the mandible was submitted to the University of Georgia Center for Applied Stable Isotope Studies for radiocarbon assay (Table 1 ). The analysis returned an age of $3360 \pm 25 \mathrm{yrs}$ BP (AGAMS\# 8554).

Test Unit 2 was excavated in the eastern portion of the shelter and reached a depth of $1.9 \mathrm{~m}$ before our field session ended (Figure 13). Lithic debitage was recovered in the unit, plus evidence of large mammal processing at the maximum depth (Figure 14). A large charcoal sample associated with the large mammal bone was identified by Kathy Puseman (2010) of PaleoResearch Institute. Charcoal of Pinus, Pseudotsuga menziesii, Salicaceae, probably Populus were identified in the sample. The Pinus fragments were submitted to the University of Georgia Center for Applied Stable Isotope Studies for radiocarbon assay (Table 1). These produced an age of $4350 \pm 25$ yrs BP (UGAMS \#8555).

Analysis of the recovered materials is ongoing and future work is planned for 2011 and beyond. 


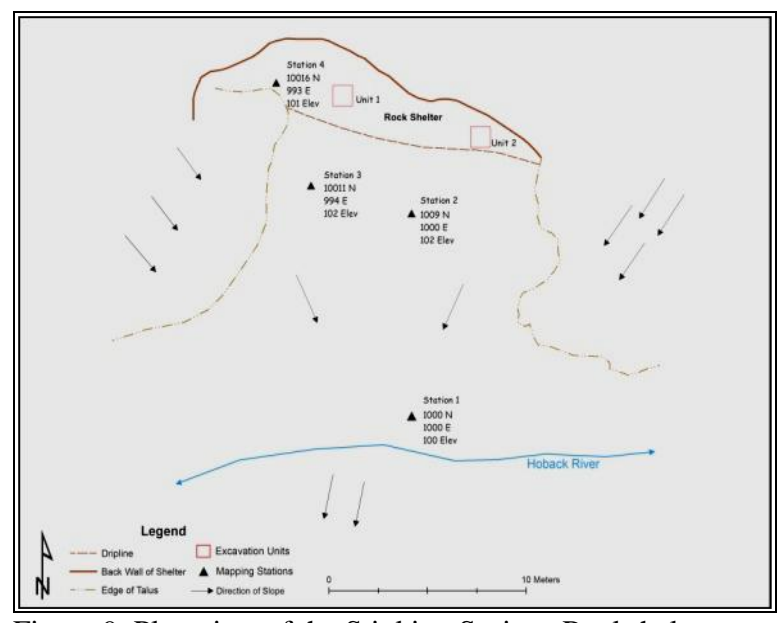

Figure 9. Plan view of the Stinking Springs Rockshelter.

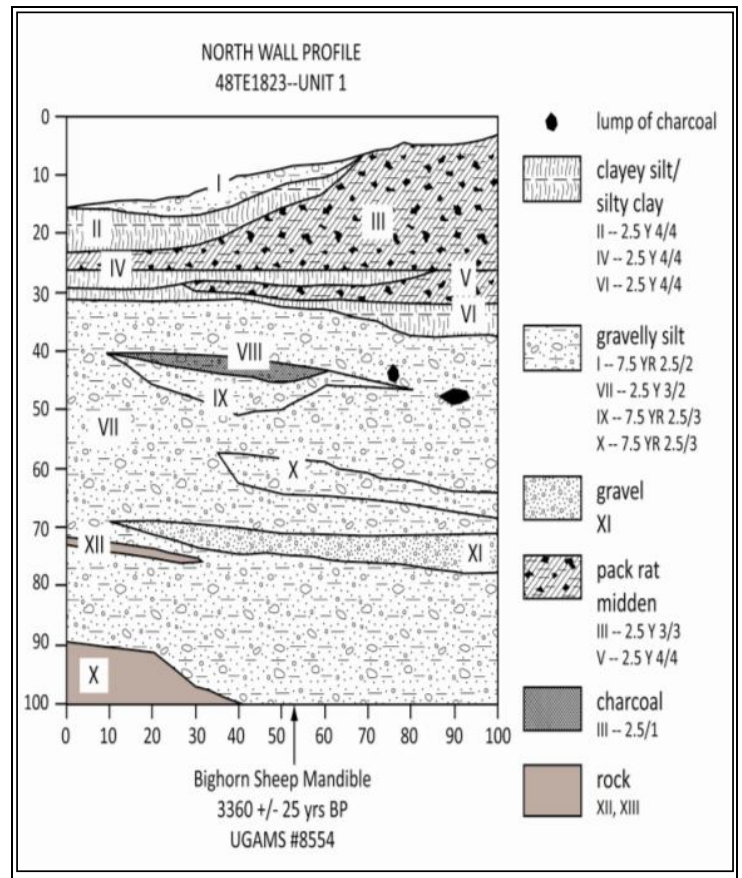

Figure 10. North wall profile of Unit 1.

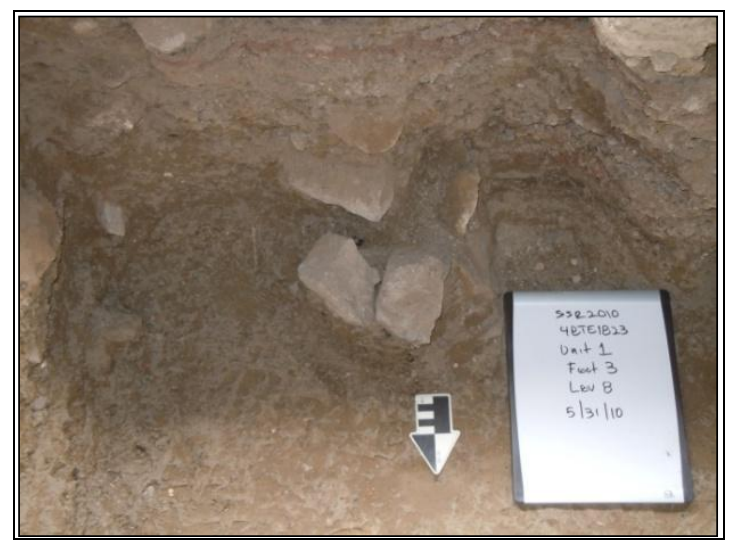

Figure 11. Fired rock feature (Feature 1) exposed in south wall of Unit 1.

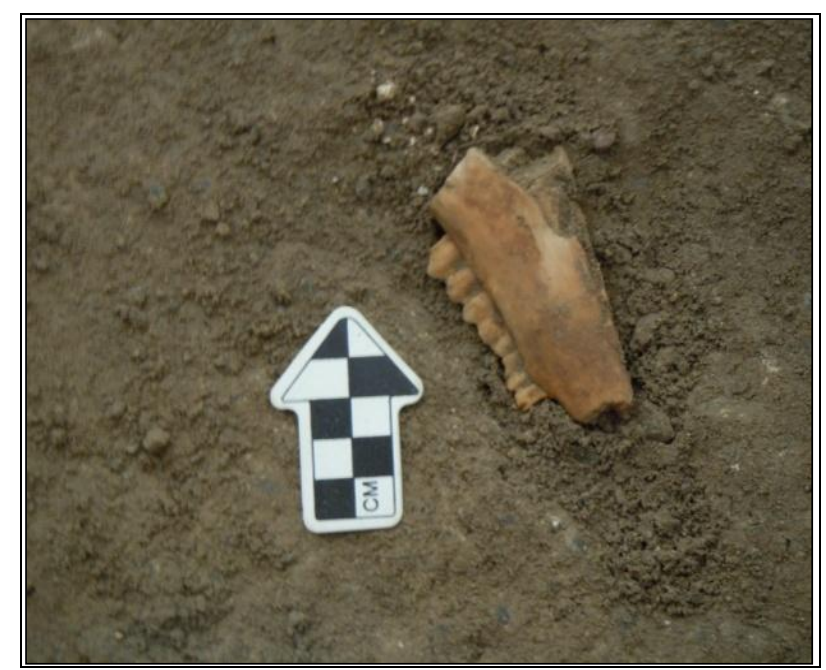

Figure 12. Bighorn sheep mandible in situ.

Table 1. Results of radiocarbon analysis for material collected in 2010.

\begin{tabular}{|c|c|c|c|c|}
\hline $\begin{array}{c}\text { UGAMS } \\
\#\end{array}$ & Material & $\begin{array}{c}\text { Radiocarbon } \\
\text { Years Before } \\
\text { Present }\end{array}$ & Sigma & $\begin{array}{c}\delta^{13} \mathrm{C} \\
\mathrm{ppm}\end{array}$ \\
\hline 8554 & Collagen & 3360 & 25 & $\begin{array}{c}- \\
19.4\end{array}$ \\
\hline 8555 & $\begin{array}{c}\text { Pinus } \\
\text { charcoal }\end{array}$ & 4350 & 25 & $\begin{array}{c}- \\
23.8\end{array}$ \\
\hline
\end{tabular}

\section{$\uparrow$ SUMMARY}

The record from the SSR has the potential to provide a detailed record, based upon hundreds and thousands of years, that can be brought to bear on the issue of wildlife management in light of future climate change, as well as providing a detailed record of human occupation and subsistence largely missing from the GYE. These are important issues highlighted in recent resource management and conservation biology publications (Irby and Knight 1997; CUMYNP 2002; Berger 2004; Lyman and Cannon 2004). Climatic histories of the past provide us with lessons for the future. Today we face many ecological problems indirectly or directly anthropogenic. By applying data from the SSR we argue that important lessons can be learned of longterm human and non-human influences on biota and ecosystems. From this perspective we can begin to understand biogeographic dynamics and behavioral patterns that are invisible to researchers who study living organisms over just a small span of years. The SSR has the potential to add significantly to this discussion. 


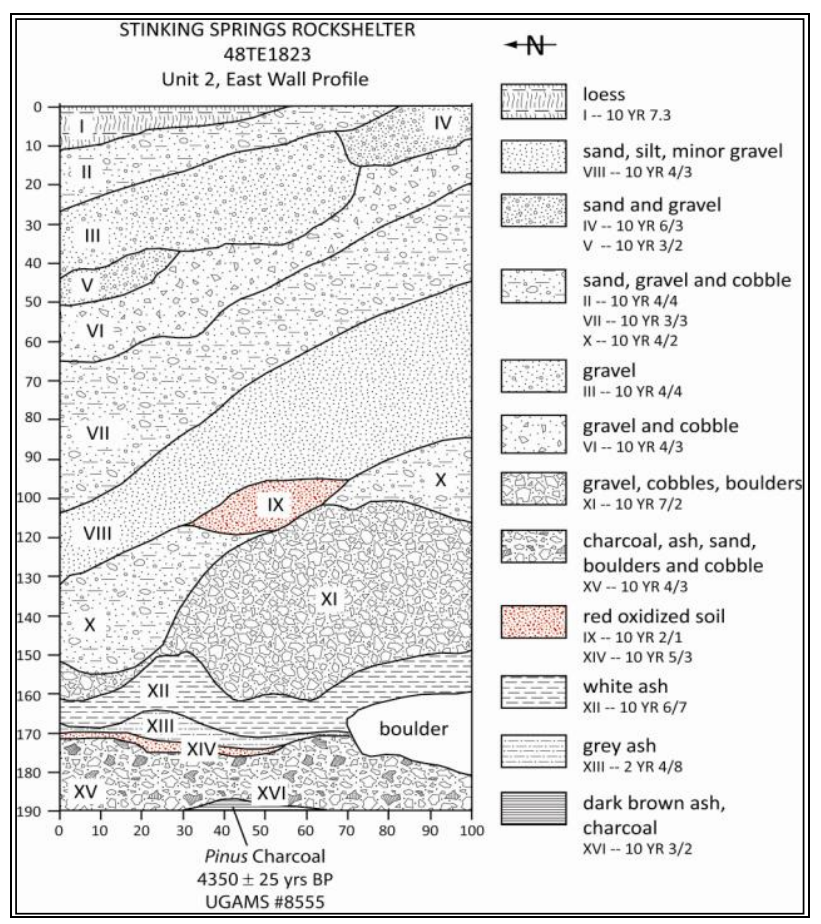

Figure 13. East wall profile of Unit 2.

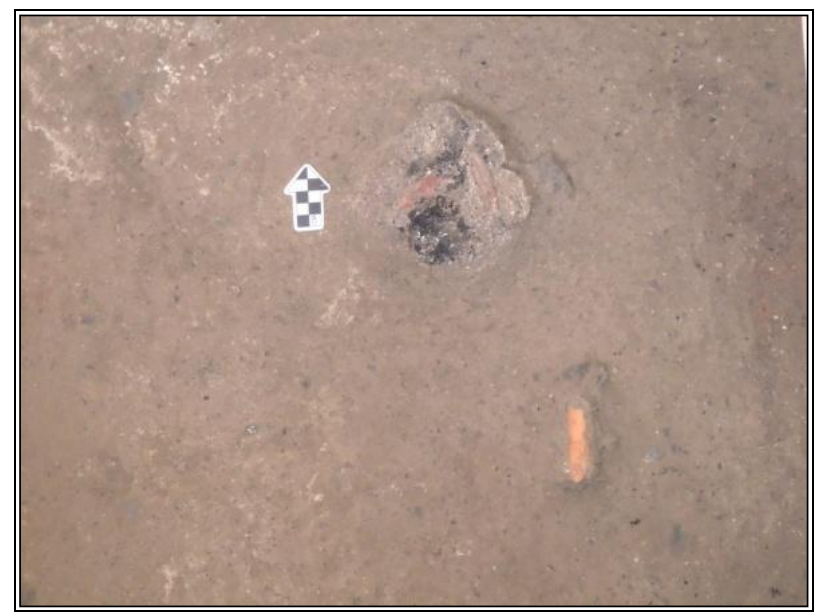

Figure 14. Large mammal bone processing area at 1.90 cmbs in Unit 2.

In summary:

- Characteristics of the rockshelter (e.g., large sheltered area under dripline, proximity to water, and southwest exposure) are similar to other rockshelters that have produced significant stratified deposits (e.g., Miller 1972; Husted and Edgar 2002).

- Evidence gathered in 2006 and 2010 indicate deep deposits with preserved organic remains that date at least to 4200 years ago.

- Caves and rockshelters in the area are rare, but the few that have been excavated provide a wealth of information in the form of stratified, organic remains that are typically not present in open sites. - The location of the rockshelter along a natural bottleneck at the entrance to Hoback Canyon is, and probably has been for millennia, a migration route for ungulates between summer and winter ranges.

- The rockshelter is within $1 \mathrm{~km}$ of several lifezones or biotic communities (cf. Clark 1999) that may have been sampled by predators increasing its relevance for addressing questions concerning the evolution of community structure in post-glacial GYA.

- The site potentially provides an important contrast to Lamar Cave (Hadly 1990) in the northern GYA which was under different climatic regimes throughout the Holocene (Whitlock and Bartlein 1993). This site provides an important test of their model which is based upon vegetation records.

- As the FAUNMAP Working Group (1996) has demonstrated, mammal communities are of relatively recent age due to individual species tolerances. With a limited record it is difficult to address complicated questions of community structure and development, the SSR can greatly increase this ability.

Understanding the relationship between past and future climatic change and its implications for ecosystem management is recognized as high-priority research needs (CUMYNP 2002). Simulation models indicate that doubling the carbon dioxide concentration in the atmosphere will produce a combination of elevational and directional range adjustments by individual plant taxa (Bartlein et al. 1997). The range of high-elevation species were reduced, and some species will become regionally extirpated. Resulting new vegetation communities have no modern analogues because they mix lowelevation montane species currently in the region with extralocal species from the northern and central Rockies and Pacific Northwest. These results are similar to those that the FAUNMAP Working Group (1996) found when analyzing the paleozoological record-mammalian species respond as individuals based on their particular tolerances and not as communities. Such response calls into question the adequacy of current management to anticipate the nature of future climatic change. As prehistorians we have the tools to provide insight into how populations in the past responded to change and to model how populations in the future may respond. 
The paleozoological record has much to offer the management of wildlife in the Greater Yellowstone Area and we believe the Stinking Springs Rockshelter has the potential to be a key resource by providing a well-preserved highresolution record of Holocene mammalian deposits.

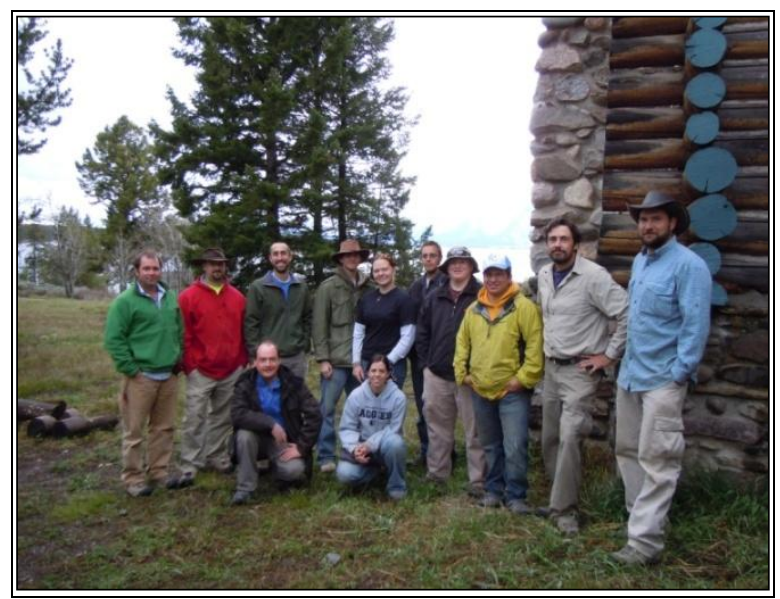

Figure 15. Utah State University 2010Archeological Field School

\section{ACKNOWLEDGEMENTS}

A number of individuals and institutions have contributed to the initial investigations of the Stinking Springs Rockshelter (Figure 15). Foremost is Jamie Schoen of the Bridger-Teton National Forest who has provided support for this project since I first started pestering him about it so many years ago. The National Speological Society has provided funding for logistical support for the 2006 and 2010 investigations. The Teton County Board of Historical Preservation provided support in 2006 that allowed us to initially assess the site. Yvette Widman assisted us with the 2006 work. We would also like to thank Dr. Hank Harlow for allowing us to use the facilities at the University of Wyoming/National Park Service Research Station in 2010. Also we would like to thank Celeste Illgner Havener for her assistance in arranging for our stay at the research station. Chris Young of the Wyoming State Historic Preservation Office provided us with site records data. Ben Marett drafted our maps and Gary O'Brien produced the excavation unit profiles. Kristin Griffin provide us with wonderful meals during the 2010 field season that kept our energy and spirits high. Especially, we would like to thank the members of the 2010 Utah State University Field School and Dr. Chris Morgan.

\section{$\uparrow \quad$ Literature Cited}

Barnosky AD, Hadly EA.1994 Ecosystem dynamics through the past 2000 years as revealed by fossil mammals from Lamar Cave in Yellowstone National Park, USA. Historical Biology 8:71-90.

Bartlein PJ, Whitlock C, Shafer S. 1997. Future Climate in the Yellostone National Park Region and Its Potential Impact on Vegetation. Conservation Biology 11(3):782-792.

Berger J. 2004. The Last Mile: How to Sustain Long-Distance Migration in Mammals. Conservation Biology 18(2):320-331.

Berger J, Cain SL, Berger KM. 2006. Connecting the Dots: An Invariant Migration Corridor Links the Holocene to the Present. Biology Letters 2:528-531.

Cannon KP. 1997. A Review of Prehistoric Faunal remains from Various Contexts in Yellowstone National Park, Wyoming. Midwest Archeological Center, Lincoln, Nebraska.

Cannon KP. 2008. Biogeography of Holocene Bison In: The Greater Yellowstone Ecosystem. Unpublished Ph.D. dissertation, Department of Geography, University of Nebraska, Lincoln.

Cannon KP, Cannon MB. 2003. Jackson Hole Bison Dig: Results of the 2002-2003 Field Investigations. Report submitted to the Earthwatch Institute, Maynard, Massachusetts.

Cannon KP, Cannon MB. Zooarcheology in the Greater Yellowstone Ecosystem. In: Lyman RL, Cannon KP editors. Zooarchaeology and Conservation Biology. University Utah Press, Salt Lake City; 2004. pp. 45-60.

Cannon KP, Nickel R. 1997. Site Relocation and Documentation in the Lemhi Valley, Idaho. Midwest Archeological Center, Lincoln, Nebraska.

Cannon KP, Bringelson D, Eckerle W, Sittler M, Boeka MS, Androy J, Roeker H. 2001. The Results of Archeological Investigations at Three Sites Along the Wilson-Fall Creek Road Corridor, Teton County, Wyoming. 
Midwest Archeological Center, Lincoln, Nebraska.

Cannon KP, Pierce KL, Stormberg P, MacMillan MV. 1997. Results of Archeological and Paleoenvironmental Investigations Along the North Shore of Yellowstone Lake, Yellowstone National Park Wyoming. Midwest Archeological Center, Lincoln, Nebraska.

Cannon KP, Sittler M, Parmalee PW. 2000. Rodent and Badger Remains from TerminalPleistocene/Holocene Deposits in Southern Jackson Hole, Wyoming. Current Research in the Pleistocene 17:115-117.

Committee on Ungulate Management in Yellowstone National Park (CUMYNP). 2002. Ecological Dynamics on Yellowstone's Northern Range. National Academy Press, Washington, D.C.

Connor MA. 1998. Final Report on the Jackson Lake Archeological Project, Grand Teton National Park, Wyoming. Technical Report No. 46, Midwest Archeological Center, Lincoln, Nebraska.

FAUNMAP Working Group. 1996. Spatial response of Mammals to Late Quaternary Environmental Fluctuations. Science 272:1601-1606.

Feeney D, Beavais G, Coupal R, Lanning S, Lieske S, Nibbelink N, Nordyke K 2004. Big Game Migration Corridors in Wyoming. University of Wyoming Cooperative Extension Service Bulletin B-1155.

Finley JB. 2001 Late Holocene Environments and Rockshelter Formation Processes in the Bighorn Mountains, Wyoming. Unpublished M.A. thesis, Department of Anthropology, Washington State University, Pullman.

Finley JB. 2007. Stratigraphy, Sedimentology, and Geomorphology. In: Frison GC, Walker DN, editors. Medicine Lodge Creek: Holocene Archaeology of the Eastern Big Horn Basin, Wyoming. Clovis Press, Avon, Colorado pp. 131-152.

Good JM, Pierce KL. 1996. Interpreting the Landscape: Recent and Ongoing Geology of Grand Teton and Yellowstone National
Parks. Grand Teton Natural History Association, Moose, Wyoming.

Hadly EA. 1990. Late Holocene Mammalian Fauna of Lamar Cave and Its Implications for Ecosystem Dynamics in Yellowstone National Park, Wyoming. Unpublished M.A. Thesis, Northern Arizona University, Flagstaff.

Hadly EA. 1995. Evolution, Ecology, and Taphonomy of Late-Holocene Mammals from Lamar Cave, Yellowstone National Park, United States of America. Unpublished Ph.D. Dissertation, Department of Integrative Biology, University of California, Berkeley.

Hadly EA. 1996. Influence of Late-Holocene Climate on Northern Rocky Mountain Mammals. Quaternary Research 46:298-310.

Hadly EA. 1999. Fidelity of terrestrial vertebrate fossils to a modern ecosystem. Palaeogeography, Palaeoclimatology, Palaeoecology Special Volume: Taphonomy and Environmental Reconstruction. 149:395-415.

Hadly EA, Kohn MH, Leonard JA, Wayne RK. 1998. A genetic record of population isolation in pocket gophers during Holocene climatic change. Proceedings of the National Academy of Sciences 95:6893-6896.

Hill C, Sutherland W, Tierney L. 1976. Caves of Wyoming. Geological Survey of Wyoming, Bulletin 59.

Hughes SS. 1988. Mummy Cave Revisited. Annals of Wyoming 60(2):44-54.

Hughes SS. 2004. Precontact Changes in the Behavior and Distribution of Rock Mountain Bighorn Sheep (Ovis canadensis) in Northwestern Wyoming. In: Lyman RL, Cannon KP, editors. Zooarchaeology and Conservation Biology. University Utah Press, Salt Lake City. pp. 116-135.

Husted WM, Edgar R. 2002. The Archeology of Mummy Cave, Wyoming: An Introduction to Shoshonean Prehistory. Special Report No. 4, Midwest Archeological Center, Lincoln, Nebraska. 
Irby L, Knight J, editors. 1997. International Symposium on Bison Ecology and Management in North America. Montana State University, Bozeman, Montana.

Kelly RL. 2010. Mummy Cave (48PA201) Draft Final Report of Activities, 2008-2010. Report in possession of author, University of Wyoming, Laramie.

Love JD. 1989. Yellowstone and Grand Teton National Parks and the Middle Rocky Mountains. Field Trip Guide T328, $28^{\text {th }}$ International Geological Congress, U.S. Geological Survey.

Lyman RL, Cannon KP. 2004. Applied Zooarchaeology, Because It Matters. In: Lyman RL, Cannon KP editors. Zooarchaeology and Conservation Biology. University Utah Press, Salt Lake City; 2004. pp. 1-24.

Miller ME, Sanders PH, Francis JE, editors. 1999. The Trappers Point Site (48SU1006): Early Archaic Adaptations in the Upper Green River Basin, Wyoming. 2 Volumes. Office of the Wyoming State Archaeologist, Cultural Resource Series No. 1.

Miller SJ. 1972. Weston Canyon Rockshelter : BigGame Hunting in Southeastern Idaho. Unpublished M.A. Thesis, Department of Anthropology, Idaho State University, Pocatello.

Plew MG. 2000. The Archaeology of The Snake River Plain. Boise State University Press, Boise, Idaho.

Puseman K. 2010. Identification of Charcoal From The Stinking Springs Rockshelter, Site 48te1823 Wyoming. PaleoResearch Institute Technical Report 10-92.
Sanders PH, Miller ME. 2004. Archaeological Evidence of Pronghorn (Antilocapra americana) Migration in the Upper Green River Basin of Wyoming: Implications for Wildlife Management. In: Lyman RL, Cannon KP editors. Zooarchaeology and Conservation Biology. University Utah Press, Salt Lake City; 2004. pp. 164-177.

Santucci VL. 1998. The Yellowstone Paleontological Survey. Yellowstone Center for Resources, YCR-NR-98-1.

Schroeder ML. 1974. Geologic Map of the Camp Davis Quadrangle, Teton County, Wyoming. U.S.G.S Geologic Quadrangle Map GQ1160 .

Whitlock C. 1993. Postglacial Vegetation and Climate of Grand Teton and Southern Yellowstone National Parks. Ecological Monographs 63(2):173-198.

Whitlock C, Bartlein PJ. 1993. Spatial Variations of Holocene Climatic Change in the Yellowstone Region. Quaternary Research 39:231-238.

Whitlock C, Dean W, Rosenbaum J, Fritz S, Bracht B, Power M. 2008. A 2650-year-long Record of Environmental Change from Northern Yellowstone National Park Based on a Comparison of Multiple Proxy. Quaternary International 188:126-138.

Wright GA. 1984. People of the High Country: Jackson Hole Before the Settlers. Peter Lang, New York.

Wright GA, Miller SJ. 1976. Prehistoric Hunting of New World Wild Sheep: Implications for the Study of Sheep Domestication. In: Cleland CE, editor, Cultural Change and Continuity: Essays in Honor of James B. Griffin. Academic Press, New York. pp. 293-318. 